\title{
Macaúba (Acrocomia aculeata) cake from biodiesel processing: a low-cost substrate to produce lipases from Moniliella spathulata R25L270 with potential application in the oleochemical industry
}

\author{
Lívia T A Souza', Jamil S Oliveira', Marina Q R B Rodrigues ${ }^{1}$, Vera L dos Santos², Benevides C Pessela ${ }^{3 *}$ \\ and Rodrigo R Resende ${ }^{4^{*}}$
}

\begin{abstract}
Background: Biodiesel industry wastes were evaluated as supplements for lipase production by Moniliella spathulata R25L270, which is newly identified yeast with great lipolytic potential. Macaúba cake (MC), used for the first time in this work as inducer to produce lipases, and residual oil (RO) were mixed to maximise enzyme production. The lipase secreted was biochemically characterised.

Results: The best ratio for the mixture (MC:RO) was 0.66:0.34 and the fitted values for lipase activity and total protein concentration were $0.98 \mathrm{U} \mathrm{mL}^{-1}$ and $0.356 \mathrm{mg} \mathrm{mL}^{-1}$, respectively. Maximum activity obtained $\left(2.47 \mathrm{U} \mathrm{mL}^{-1}\right.$ ) was achieved at $31.5^{\circ} \mathrm{C}$ and $\mathrm{pH} 6.7$, and the enzyme was stable in this condition. A novel enzyme was purified and identified for the first time by mass spectrometry. The lipase efficiently hydrolysed different natural oils and exhibited selectivity in the production of eicosapentaenoic acid from fish oil.

Conclusion: The use of MC and RO as a supplement to produce the new lipase from M. spathulata R25L270 may be one alternative for reducing lipase production costs and simultaneously adding value to biodiesel industry residues. The potential application of the lipase in the oleochemical industry was demonstrated by its $\mathrm{pH}$ and temperature stabilities and selective hydrolysis.
\end{abstract}

Keywords: Macaúba cake, Lipases, Yeast, Moniliella spathulata, Submerged fermentation, Hydrolysis, Oils, Biodiesel

\section{Background}

The increase in global biodiesel demand is evident; however, the following two main challenges still reduce the economic viability of this renewable fuel: (a) the feedstock

\footnotetext{
*Correspondence: b.pessela@csic.es; rrresende@hotmail.com

${ }^{3}$ Departamento de Biotecnología y Microbiología de Alimentos, Instituto de Investigación en Ciencias de la Alimentación CIAL (CSIC-UAM), Campus de la Universidad Autónoma de Madrid, Nicolás Cabrera 9, 28049 Madrid, Spain

${ }^{4}$ Instituto Nanocell and Departamento de Bioquímica e Imunologia, Instituto de Ciências Biológicas, Universidade Federal de Minas Gerais, Av Antônio Carlos 6627, Pampulha, Caixa Postal 486, Belo Horizonte, MG 31270-901, Brazil

Full list of author information is available at the end of the article
}

cost and (b) the high volume of glycerol and residues generated by the production process $[1,2]$. One way to eliminate these wastes is to provide added value based on their utilization to produce biotechnological products such as enzymes and other bio products. In this context, the use of lipid-rich waste as substrate for the production of microbial lipases has been demonstrated as a viable technique to reduce the enzyme cost while solving the pollution problems caused by the disposal of these residues [3]. In this work, three residues from biodiesel processing (macaúba cake, residual oil and residual water) were evaluated with respect to their potential use in lipase production by Moniliella spathulata R25L270. Biodiesel 
processing of the Macaúba palm (Acrocomia aculeata) was chosen due to its great use in Brazilian industry to biodiesel production as a feedstock with the potential to produce $1,500-5,000 \mathrm{~kg}$ oil ha ${ }^{-1}$, which is only lower to the production of palm oil (Elaeis guineensis) [4]. The use of Macaúba oil in Brazil is escalating at a remarkable rate to increase the commercial competitiveness of biofuel and support development in the producing areas [5].

Lipases (EC. 3.1.1.3) are able to modify triglycerides and other esters at the water-oil interface by catalysing hydrolysis and synthesis reactions [6]. Because of their versatility and specificity, lipases are promising enzymes for use in the oleochemical industry. The world's consumption of fatty acids and fatty alcohols in 2010 was 6 and 2.5 million tons, respectively, and is expected to reach 7.5 and 3.5 million tons in 2020 [7]. Furthermore, lipases are sold in large volumes for use in other industrial applications, for example, in detergent formulation, food processing, biodiesel production, racemic resolution, pharmaceuticals, and waste treatment [6].

Yeast lipases have a great importance in the enzyme market due their solubility, temperature and $\mathrm{pH}$ stabilities. Candida, Rhodotorula, Debaryomyces, Trischosporon and Yarrowia are the main genera with species that produce lipases [8]. The strain used in this work, $M$. spathulata R25L270, was isolated from Brazilian butter cheese (Requeijão do Norte), and its potential lipolytic was recently revealed (date submitted). However, there is not description or identification of the lipases it produces. Hence, the aims of this study were to evaluate and maximise lipase production in low-cost culture medium using biodiesel process residues followed by biochemical characterisation, purification, identification and application of the produced lipases in catalysis of the hydrolysis of vegetal and fish oils.

\section{Methods}

\section{Microorganism and inoculum}

The strain M. spathulata R25L270 from the culture collection of the Universidade Federal de Minas Gerais (Brazil) was isolated from Brazilian butter cheese (Requeijão do Norte), and its lipolytic potential has been recently identified (submitted for publication). Cultures of this yeast were maintained in GYMP broth (glucose $20 \mathrm{~g} \mathrm{~L}^{-1}$, yeast extract $5 \mathrm{~g} \mathrm{~L}^{-1}$, malt extract $10 \mathrm{~g} \mathrm{~L}^{-1}, \mathrm{NaH}_{2} \mathrm{PO}_{4}$ $2 \mathrm{~g} \mathrm{~L}^{-1}$ and glycerol $20 \mathrm{l} \mathrm{L}^{-1}$ ) at $-80^{\circ} \mathrm{C}$. For inoculum preparation, fresh cells of the yeast cultivated on Sabouraud agar medium composed of glucose $20 \mathrm{~g} \mathrm{~L}^{-1}$, peptone $10 \mathrm{~g} \mathrm{~L}^{-1}$ and yeast extract $5 \mathrm{~g} \mathrm{~L}^{-1}$ were used. Cells were grown with shaking at $30^{\circ} \mathrm{C}(200 \mathrm{rpm})$ for $24 \mathrm{~h}$. The cells were then recovered by centrifugation $(5,000 \times g$, $10 \mathrm{~min}$ ) and suspended in the fermentation medium at the desired initial culture density $\left(\mathrm{DO}_{600}=0.1\right)$.

\section{Experimental procedure for lipase production using biodiesel wastes}

Fermentation assays to evaluate the possibility of using waste from biodiesel industry as a supplement for lipase production were performed in three consecutive stages. First, the influence of nitrogen sources $\left(20 \mathrm{~g} \mathrm{~L}^{-1}\right)$ such as peptone G, water peptone, bacteriological peptone, proteose peptone, bacto-tryptone and peptone A on lipase activity was evaluated. These assays were performed in $250 \mathrm{~mL}$ Erlenmeyer flasks containing $50 \mathrm{~mL}$ of medium composed of $\mathrm{NH}_{4} \mathrm{NO}_{3} 1 \mathrm{~g} \mathrm{~L}^{-1} ; \mathrm{KH}_{2} \mathrm{PO}_{4} 1 \mathrm{~g} \mathrm{~L}^{-1} ; \mathrm{MgSO}_{4} \cdot 7 \mathrm{H}_{2} \mathrm{O} 5 \mathrm{~g} \mathrm{~L}^{-1}$; and $10 \mathrm{~g} \mathrm{~L}^{-1}$ of olive oil at $\mathrm{pH} 6.5$. In the second step, the medium containing the best nitrogen source (peptone A) was supplemented with macaúba cake obtained from fruit pulp (40 $\left.\mathrm{g} \mathrm{L}^{-1}\right)$, oil residual extracted from diatomaceous earth $\left(10 \mathrm{~g} \mathrm{~L}^{-1}\right)$ or liquid effluent collected from washing biodiesel tanks $\left(500 \mathrm{l} \mathrm{L}^{-1}\right)$ to evaluate the potential use of these oil sources for lipase production. In the last stage, a simplex lattice mixture design was used to study the effects of binary blends of macaúba cake and residual oil (MC:RO) on lipase secretion in terms of enzyme activity and concentration. The MC:RO proportions study and the respective observed and adjusted responses obtained: For MC, the maximal concentration assayed (100:0) was $40 \mathrm{~g} \mathrm{~L}^{-1}$, and for RO the maximal concentration assayed $(0: 100)$ was $10 \mathrm{~g} \mathrm{~L}^{-1}$. In all cases, after inoculation at the initial optical density $\left(\mathrm{DO}_{600}=0.1\right)$, the flasks were incubated in a rotary shaker at $30^{\circ} \mathrm{C}$ and $200 \mathrm{rpm}$ for $120 \mathrm{~h}$. The cells were then recovered by centrifugation $(8,000 \times g, 10 \mathrm{~min})$, and their supernatants were used for the determination of lipase activity. Regression models were adjusted to explain the influence of the MC:RO proportion on the extracellular lipase activity and total protein concentration in the supernatant. The adjusted models were then used to estimate the optimal proportion for the two response variables using a desirability function. Statistical analysis and graphing were performed with MINITAB 16 (Stat-Ease, Inc., Minneapolis, MN, USA) using a $95 \%$ confidence cut-off $(\alpha=0.05)$.

\section{Lipase activity assay}

Activity was continuously followed spectrophotometrically by the increase in the absorbance at $410 \mathrm{~nm}$ caused by the hydrolysis of $p$-nitrophenyl palmitate ( $p$-NPP) using a Varioskan microplate reader $[9,10]$. One unit of lipase $(\mathrm{U})$ was defined as the amount of enzyme that releases $1 \mu \mathrm{mol} p$-nitrophenol $(p \mathrm{NP})$ per min in the assay conditions ( $\left.\mathrm{pH} 8.0,37^{\circ} \mathrm{C}\right)$.

\section{Biochemical characterisation of $M$. spathulata R25L270 lipase}

All tests were conducted in triplicate using the crude supernatant obtained during cultivation of the yeast in medium supplemented with olive oil. 


\section{Storage stability}

Crude lipase storage stability was evaluated by storing the cell-free culture supernatant at the following temperatures: freezer $\left(-20^{\circ} \mathrm{C}\right)$, ultra-freezer $\left(-80^{\circ} \mathrm{C}\right)$ and refrigerator $\left(4^{\circ} \mathrm{C}\right)$. Lipase activity was measured every 7 days using the lipase activity assay described above.

\section{Determination of $\mathrm{pH}$ and temperature optimum of lipase}

A central composite design $\left(2^{2}+2 \times 2+5\right)$ was employed to study the influence of reaction $\mathrm{pH}$ and temperature on M. spathulata R25L270 lipase activity. The experimental matrix assayed is presented in Table 1. Each parameter combination was repeated at least twice. The lipase activity response $\left(\mathrm{U} \mathrm{mL}^{-1}\right)$ was measured using the lipase activity assay described above. The experimental design and regression analysis were performed with MINITAB 16 software, and the response surface plot was generated by Sigma Plot 10.0 software.

Table 1 Central composite design matrix used to study the influence of reactional temperature $\left({ }^{\circ} \mathrm{C}\right)$ and $\mathrm{pH}$ on lipase activity $\left(\mathrm{U} \mathrm{mL}^{-1}\right)$ and the respective observed $(y)$ and fitted $(\hat{y})$ values and residual errors $(\varepsilon)$

\begin{tabular}{|c|c|c|c|c|}
\hline \multicolumn{2}{|c|}{ Central composite design } & \multicolumn{3}{|c|}{ Lipase activity $\left(\mathrm{U} \mathrm{mL}^{-1}\right)$} \\
\hline Temperature $\left({ }^{\circ} \mathrm{C}\right)$ & $\mathrm{pH}$ & y & $\hat{y}$ & $\varepsilon$ \\
\hline 45 & 6.5 & 2.44 & 2.17 & 0.271 \\
\hline 45 & 6.5 & 2.48 & 2.17 & 0.319 \\
\hline 45 & 6.5 & 2.32 & 2.17 & 0.151 \\
\hline 45 & 9.5 & 0.88 & 1.08 & -0.200 \\
\hline 45 & 9.5 & 0.88 & 1.08 & -0.196 \\
\hline 45 & 9.5 & 0.86 & 1.08 & -0.219 \\
\hline 45 & 8 & 2.09 & 1.94 & 0.147 \\
\hline 45 & 8 & 1.90 & 1.94 & -0.042 \\
\hline 45 & 8 & 1.88 & 1.94 & -0.056 \\
\hline 45 & 8 & 1.93 & 1.94 & -0.006 \\
\hline 45 & 8 & 1.90 & 1.94 & -0.042 \\
\hline 65 & 8 & 0.48 & 0.39 & 0.080 \\
\hline 65 & 8 & 0.49 & 0.39 & 0.091 \\
\hline 25 & 8 & 2.15 & 2.17 & -0.015 \\
\hline 25 & 8 & 2.14 & 2.17 & -0.031 \\
\hline 30.8 & 6.94 & 2.30 & 2.46 & -0.161 \\
\hline 30.8 & 6.94 & 2.31 & 2.46 & -0.155 \\
\hline 30.8 & 6.94 & 2.41 & 2.46 & -0.052 \\
\hline 30.8 & 9.06 & 1.75 & 1.70 & 0.054 \\
\hline 30.8 & 9.06 & 1.78 & 1.70 & 0.079 \\
\hline 30.8 & 9.06 & 1.96 & 1.70 & 0.262 \\
\hline 59.1 & 6.94 & 0.89 & 1.21 & -0.324 \\
\hline 59.1 & 6.94 & 0.82 & 1.21 & -0.393 \\
\hline 59.1 & 9.06 & 0.65 & 0.45 & 0.200 \\
\hline 59.1 & 9.06 & 0.68 & 0.45 & 0.236 \\
\hline
\end{tabular}

\section{Thermostability of M. spathulata R25L270 lipase}

The thermostability of the enzyme was studied at different $\mathrm{pH}$ and temperature conditions. The crude lipase supernatant was diluted $1: 1(\mathrm{v} / \mathrm{v})$ in $50 \mathrm{mM}$ Tris $-\mathrm{HCl}$ buffers $\mathrm{pH}(6.5,7.5$ and 8.5$)$ and incubated at 45 and $50^{\circ} \mathrm{C}$, respectively. Samples were taken at determined interval times, and the enzyme activity was immediately measured using the standard assay. The residual activity was calculated by taking the enzyme activity at $0 \mathrm{~min}$ incubation as $100 \%$.

\section{One-step purification/immobilization of lipases from M. spathulata R25L270 on phenyl-Sepharose}

Phenyl-Sepharose $(1 \mathrm{~g})$ was suspended in $8 \mathrm{~mL}$ of crude supernatant culture containing approximately 0.8 $\mathrm{U} \mathrm{mL} \mathrm{m}^{-1}$ of lipases and $2 \mathrm{mg}$ of total protein and $2 \mathrm{~mL}$ of phosphate buffer ( $5 \mathrm{mM}, \mathrm{pH} 7)$. The suspensions were gently stirred at room temperature. At 10-min intervals, samples of the suspensions were withdrawn and centrifuged $(8,000 \times g ; 3 \mathrm{~min})$ to obtain the supernatants, and their enzyme activity was analysed as described above ("Lipase activity assay"). After immobilization, the suspension was filtered in a sintered glass filter and vacuum dried. Proteins were desorbed by suspending the immobilized enzyme in a 1:10 (w/v) ratio of $25 \mathrm{mM}$ sodium phosphate at $\mathrm{pH} 7.0$ and $25^{\circ} \mathrm{C}$ containing different concentrations $[0.02 \%$ until $0.1 \%(\mathrm{v} / \mathrm{v})]$ of Triton X-100 until full desorption [11].

\section{SDS-PAGE analysis}

The protein profile of the culture supernatant was determined by SDS-PAGE using a Laemmli system with $12.5 \%$ acrylamide [12]. The proteins were stained with Coomassie blue dye [13] and Schiff reagent [14]. A native PAGE with $10 \%$ acrylamide was also done for it the gel was prepared without SDS and the samples were not boiled before loading in the gel. The lipase activity in the gel was detected using tributyrin as the substrate according to [15].

\section{Protein identification by mass spectrometry (MS)}

The profile of protein desorbed with a gradient of Triton X-100 was analysed by SDS-PAGE. The observed bands were analysed by MS at the Centro de Biología Molecular Severo Ochoa, CBM-CSIC campus Universidad Autónoma de Madrid, Plataforma in Red de Proteómica Carlos III. After drying, gel bands or spots were destained in acetonitrile:water $\left(\mathrm{ACN}: \mathrm{H}_{2} \mathrm{O}, 1: 1\right)$ and digested in situ with sequencing-grade trypsin (Promega, Madison, WI), according to Shevchenko et al. [16]. The desalted protein digest was dried, resuspended in $10 \mu \mathrm{L} 0.1 \%$ formic acid and analysed by RP-LC-MS/MS in an Easy-nLC II system coupled to an ion trap LTQ-Orbitrap-Velos-Pro 
mass spectrometer (Thermo Scientific). The peptides were concentrated (on-line) by reverse phase chromatography using a $0.1 \mathrm{~mm} \times 20 \mathrm{~mm} \mathrm{C18} \mathrm{RP} \mathrm{precolumn}$ (Acclaim PepMap 100, nanoViper, Thermo Scientific) and then separated using a $0.075 \mathrm{~mm} \times 250 \mathrm{~mm}$ C18 RP column (Acclaim PepMap ${ }^{\oplus} 100$, nanoViper, Thermo Scientific) operating at $0.3 \mu \mathrm{L} \mathrm{min}{ }^{-1}$. Peptides were eluted using a $90-$ min gradient of $5-40 \%$ solvent (solvent A: $0.1 \%$ formic acid in water, solvent B: $0.1 \%$ formic acid, $80 \%$ acetonitrile in water). ESI ionisation was performed using a Nano-bore emitter Stainless Steel ID $30 \mu \mathrm{m}$ (Proxeon) interface. The Orbitrap resolution was set at 30,000 . Peptides were detected in survey scans from 400 to 1,600 amu ( 1 uscan), followed by 15 data-dependent MS/MS scans (Top 15) using an isolation width of $2 \mathrm{u}$ (in mass-to-charge ratio units), normalised collision energy of $35 \%$, and dynamic exclusion applied during 30-s periods. Peptide identification from raw data was carried out using the SEQUEST HT algorithm (Proteome Discoverer 1.4, Thermo Scientific). A database search was performed against uniprot-fungi.fasta. The following constraints were used for the searches: tryptic cleavage after Arg and Lys, up to two missed cleavage sites, and tolerances of $20 \mathrm{ppm}$ for precursor ions and 0.8 Da for MS/MS fragment ions. The searches were performed allowing optional Met oxidation and Cys carbamidomethylation. The search was performed against a decoy database (integrated decoy approach) using a false discovery rate (FDR) $<0.01$.

\section{Hydrolysis of vegetal and fish oil}

The hydrolytic activity of lipase from M. spathulata R25L270 was determined for emulsified vegetable oils (corn, sunflower, soybean, olive, canola, pequi, almond, macaúba and sesame) according to Soares et al. [17]. The fatty acids formed were titrated with $20 \mathrm{mM}$ sodium hydroxide solution in the presence of phenolphthalein as an indicator. One international unit (U) of activity was defined as the amount of enzyme that releases $1 \mu \mathrm{mol}$ free fatty acid per minute under the assay conditions. Fish oil hydrolysis was performed in presence of cyclohexane, as proposed by Fernández-Lorente et al. [18]. The concentration of free fatty acids in the organic phase was determined by RP-HPLC (Spectra Physic SP 100 coupled with a UV detector SpectraPhysic SP 8450) using a reversed-phase column (Ultrabase C18, $4.6 \mathrm{~mm}$ i.d. $\times 150 \mathrm{~mm}, 5 \mu \mathrm{m}$ particle) [18].

\section{Results and discussion}

\section{Production of lipases by M. spathulata R25L270 grown on biodiesel waste}

The primary objective of this work was to analyse the suitability of biodiesel residues as a substrate for the growth of M. spathulata R25L270 and lipase production. Lipase production was studied using the following consecutive analyses: (a) effect of organic nitrogen source, (b) effect of individual biodiesel residues and (c) mixture of biodiesel residues. Nitrogen sources play a crucial role in regulating the synthesis of hydrolases, and the production of fungal lipases appears to require a high concentration of nitrogen compared to the production of other enzymes [19]. As shown in Table 2, among the organic nitrogen sources tested in this work, peptone A and bacto-tryptone exhibited the highest lipase activities $(0.69 \pm 0.03$ and $0.63 \pm 0.07 \mathrm{U} \mathrm{mL}^{-1}$, respectively) and supported good cell growth (25.0 and $28.2 \mathrm{OD} \mathrm{nm}$, respectively). In contrast, water peptone $\left(0.03 \pm 0.0 \mathrm{U} \mathrm{mL}^{-1}\right)$ and peptone $\mathrm{G}(0.0$ $\mathrm{U} \mathrm{mL}^{-1}$ ) showed inhibition of lipase activity compared to bacteriological peptone $\left(0.34 \pm 0.4 \mathrm{U} \mathrm{mL}^{-1}\right)$, the most commonly used peptone. The nitrogen sources differed in their nutritive value, degree of peptide hydrolysis and amino acid content; these factors are associated with the specific nutritional requirements of yeast and can explain the influence on growth and lipase production. For Yarrowia lipolytica, the highest level of lipase activity was obtained in the presence of casein hydrolysate (tryptone $\mathrm{N}_{1}$ ), and formulation media containing casamino acids led to low lipolytic productivity [20]. Candida viswanathii presented high cell growth and lipase production when cultivated in Vogel's medium supplemented with peptone, tryptone and yeast extract. However, the use of urea, $\mathrm{NH}_{4} \mathrm{Cl}$ and $\left(\mathrm{NH}_{4}\right)_{2} \mathrm{SO}_{4}$ inhibited lipase secretion but supported cell growth [21].

After selecting the most suitable organic nitrogen source for the secretion of lipases by M. spathulata R25L270 cultivated in medium with olive oil as an inducer, the basal liquid medium was supplemented individually with three different residues from the macaúba biodiesel production process, macaúba cake, residual oil, and liquid waste. The lipase activity and yeast growth were monitored. There was no growth of the yeast strain in medium supplemented with liquid waste. The microbial growth inhibition caused by this substrate may be associated with the addition of potassium hydroxide required to elevate the $\mathrm{pH}$ of these

Table 2 Effect of organic nitrogen source on lipase secretion and growth of M. spathulata R25L270

\begin{tabular}{lcc}
\hline Nitrogen source & Lipase activity $\left(\mathbf{U ~ m L}^{-\mathbf{1}}\right)$ & Growth $\mathbf{O D}_{\mathbf{6 0 0} \mathbf{~ n m}}$ \\
\hline Peptone G & $0 \pm 0$ & 9.4 \\
Water peptone & $0.03 \pm 0.0$ & 25.6 \\
Peptone bacteriological & $0.34 \pm 0.03$ & 23.8 \\
Proteose peptone & $0.46 \pm 0.02$ & 14.4 \\
Bacto-typtone & $0.63 \pm 0.07$ & 28.2 \\
Peptone A & $0.69 \pm 0.03$ & 25.0 \\
\hline
\end{tabular}


residues from 1.5 to 6.5 or the presence of contaminants and trace solvents. The low $\mathrm{pH}$ of the effluent is associate with the addition of acid required to neutralization and washing biodiesel step [22]. When the yeast was cultivated in medium enriched with residual oil instead of olive oil, the extracellular lipase activity was $0.37 \pm 0.08$ $\mathrm{U} \mathrm{mL}{ }^{-1}$, but good growth of the yeast was not observed. According Monteiro et al. [23] the composition of this residual oil indicated the presence of hexadecanoic acid (22.92\%), 9,12-octadecadienoic acid (36.74\%), 9-octadecenoic acid (34.74\%), and octadecanoic acid (5.60\%) [23]. Lipase activity was better when the medium was supplemented with olive oil $\left(0.69 \mathrm{U} \mathrm{mL}^{-1}\right)$ as compared with the medium supplemented only with residual oil $\left(0.37 \mathrm{U} \mathrm{mL}^{-1}\right)$, probably due the lower content of 9-octadecenoic acid. Certain oil residues, such as grease wastes, inhibit microorganism growth and/or lipase secretion because of this different agro-waste residues, such as wheat bran, rice bran, and oil cake, are used in combination [24]. The maximum lipolytic activity $(0.7 \pm 0.04$ $\mathrm{U} \mathrm{mL}^{-1}$ ) was achieved when the yeast was grown in a macaúba cake-supplemented medium. In this fermentation condition, it was not possible to measure the optical density of the culture due to the presence of suspended solids and turbidity, so we cannot link maximal lipolytic activity and growth.

To study the influence of the macaúba cake (MC) and residual oil (RO) mixture on lipase secretion by $M$. spathulata R25L270, a simplex centroid mixture design was used. The levels of the two factors were selected based on preliminary studies carried out in our laboratory. The experimental design and the results of the mixture trials are presented in the Table 3. Sequential model fitting of the lipase activity $\left(\mathrm{U} \mathrm{mL}^{-1}\right)$ and total protein concentration $\left(\mathrm{mg} \mathrm{mL}^{-1}\right)$ showed that the quadratic model is the most appropriate to explain the influence of the MC:RO mixture on lipase secretion by $M$. spathulata R25L270 as shown in Eqs. (1) and (2).

$$
\begin{aligned}
& \mathrm{LA}=0.733 \mathrm{MC}+0.065 \mathrm{RO}+2.113 \mathrm{MC} \cdot \mathrm{RO} \\
& \mathrm{LP}=0.326 \mathrm{MC}+0.098 \mathrm{RO}+0.479 \mathrm{MC} \cdot \mathrm{RO}
\end{aligned}
$$

where, LA corresponds to lipase activity $\left(\mathrm{U} \mathrm{mL}^{-1}\right)$, LP corresponds to total protein $\left(\mathrm{mg} \mathrm{mL}^{-1}\right), \mathrm{MC}$ corresponds to macaúba cake proportion, and $\mathrm{RO}$ corresponds to residual oil proportion.

Analysis of variance (ANOVA) of the quadratic response surface model was used to assess the adequacy of the model and showed that the two adjusted models can significantly $(\mathrm{p}$ value $=0.000$ and $\mathrm{p}$ value $=0.002$, for LA and LP, respectively) explain the variation in responses based on the different MO:RO proportions in the medium. The $\mathrm{R}^{2}$ values indicated that 95.91 and $87.85 \%$ of the observed variation in supernatant lipase activity and total protein concentration, respectively, can be explained by this model. The significant, positive and relatively strong interaction between macaúba cake $(\mathrm{MC})$ and residual oil ( $\mathrm{RO}$ ) observed in both adjusted equations (Eqs. 1, 2) reveal the existence of synergism between the two components of the mixture. The Cox response trace plots for fitted LA and LP are presented in Figure 1. By using a composite desirability tool and the adjusted equations for LA and LP to maximise both responses simultaneously, we found that the best ratio for the mixture is 0.66:0.34 (MC:RO) and the fitted values for LA and LP are $0.98 \mathrm{U} \mathrm{mL}^{-1}$ and $0.356 \mathrm{mg} \mathrm{mL}^{-1}$, respectively. There

Table 3 Simplex lattice mixture design matrix used to study the influence of macaúba cake and residual oil mixture on lipase secretion by M. sphatulata R25L270 presenting the MC:RO proportions and the respective observed (y) and fitted $(\hat{y})$ values and residual errors $(\varepsilon)$ for supernatant lipase activity $\left(\mathrm{U} \mathrm{mL}^{-1}\right)$ and supernatant total protein $\left(\mathrm{mg} \mathrm{mL}^{-1}\right)$

\begin{tabular}{|c|c|c|c|c|c|c|c|}
\hline \multicolumn{2}{|c|}{ Simplex lattice mixture design } & \multicolumn{3}{|c|}{ Lipase activity $\left(\mathrm{U} \mathrm{mL}^{-1}\right)$} & \multicolumn{3}{|c|}{ Total protein concentration $\left(\mathrm{mg} \mathrm{mL}^{-1}\right)$} \\
\hline MC proportion & RO proportion & $\mathbf{y}$ & $\hat{y}$ & $\varepsilon$ & y & $\hat{y}$ & $\varepsilon$ \\
\hline 1.00 & 0.00 & 0.79 & 0.73 & 0.056 & 0.399 & 0.326 & 0.0726 \\
\hline 0.00 & 1.00 & 0.04 & 0.07 & -0.026 & 0.098 & 0.098 & 0.0003 \\
\hline 0.50 & 0.50 & 1.02 & 0.93 & 0.092 & 0.318 & 0.332 & -0.0139 \\
\hline 0.75 & 0.25 & 0.85 & 0.96 & -0.113 & 0.321 & 0.359 & -0.0381 \\
\hline 0.25 & 0.75 & 0.69 & 0.63 & 0.061 & 0.248 & 0.245 & 0.0032 \\
\hline 1.00 & 0.00 & 0.77 & 0.73 & 0.036 & 0.273 & 0.326 & -0.0534 \\
\hline 0.00 & 1.00 & 0.04 & 0.07 & -0.026 & 0.09 & 0.098 & -0.0077 \\
\hline 0.50 & 0.50 & 0.96 & 0.93 & 0.032 & 0.381 & 0.332 & 0.0491 \\
\hline 0.75 & 0.25 & 0.85 & 0.96 & -0.113 & 0.347 & 0.359 & -0.0121 \\
\hline
\end{tabular}
responses 
is a range (from 0.639 to 0.675 of $\mathrm{MC}$ ) in which the fitted value for LA is $0.98 \mathrm{U} \mathrm{mL}^{-1}$, so we present these values as the best combinations to obtain lipase activity and protein. These novel fermentation conditions can be used instead of olive oil for the induction of lipase secretion by M. spathulata R25L270. Additionally, this experimental design can be applied to study the potential use of mixtures of biodiesel residuals as substrates for lipase production by other yeasts.

In general, the microbial pattern of lipase production is associated with cell growth and substrate consumption, and it occurs in stress conditions. At the initial stage, cell-bound lipase (at basal levels) is able to hydrolyse the lipid (inducer) present in the substrate at a reaction rate high enough to start cell growth and enzyme expression [25]. As fermentation continues and substrate
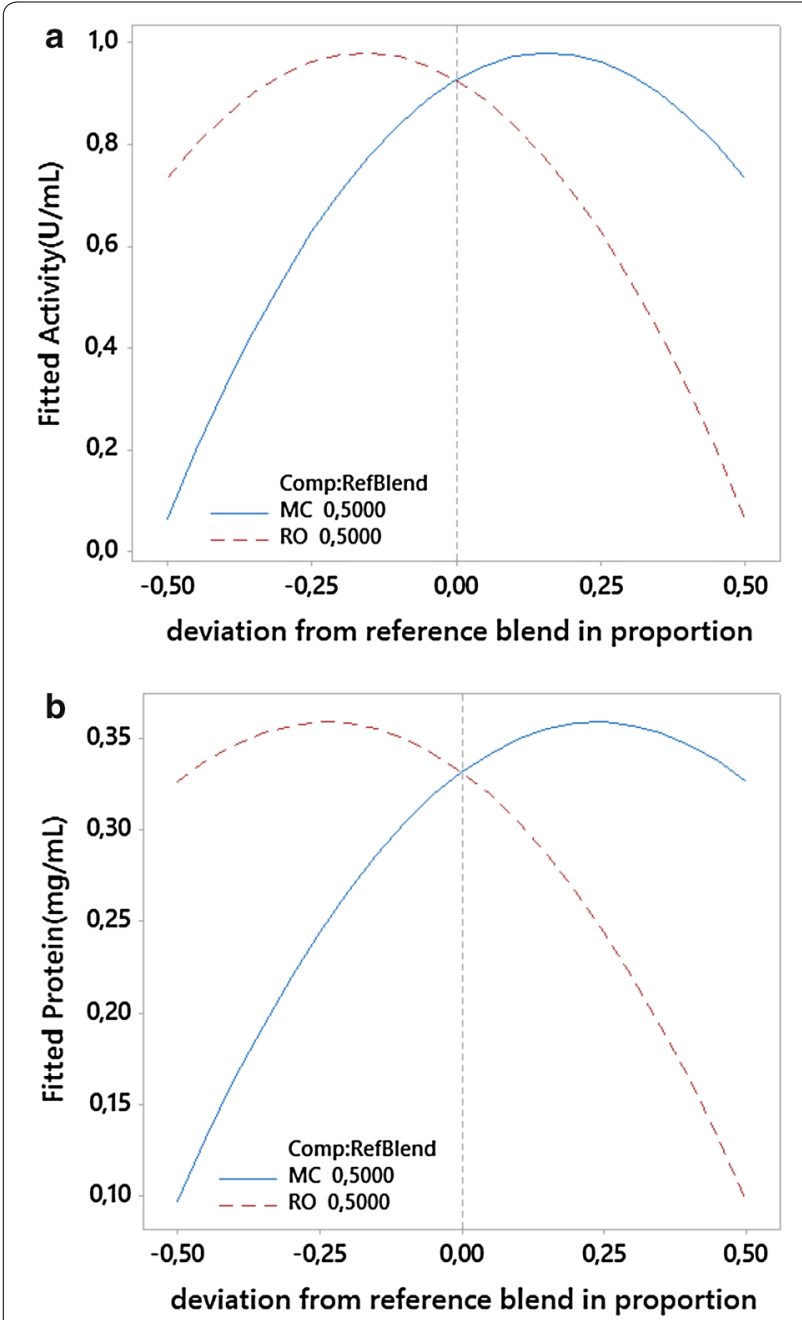

Figure 1 Cox response trace plot for fitted supernatant lipase activity $\left(\mathrm{U} \mathrm{mL}^{-1}\right)(\mathbf{a})$ and supernatant total protein concentration $\left(\mathrm{mg} \mathrm{mL}^{-1}\right)$ (b) versus the MC:RO deviation proportions from the reference blend 0.5:0.5 for MC (solid line) or RO (dashed line). availability decreases, the production of extracellular lipases becomes necessary to promote substrate uptake and ensure cell survival [25]. At this time, enzyme release increases the probability of enzyme-substrate contact and nutrient assimilation [25]. This mechanism is generally dependent on cellular regulatory mechanisms elicited by the components of the substrates, mainly lipid inducers.

The yeast $M$. spathulata R25L270 was recently described as a microorganism with lipolytic potential, and its nutritional requirements for lipase secretion are unknown. Oil cakes contain residual nutrients that can serve as both carbon and nitrogen sources. The use of oil cakes such as babassu [26], Jatropha curcas [27], soybean [28], mustard [29], sesame [30], coconut [30], and ground nut [30] has been successful used to obtain lipases from different microorganisms.

We report the first use of macaúba cake for lipase production. Macaúba cake is composed of crude protein, fibre and lipids and has an elemental composition of $\mathrm{C}$ 50.93\%, O 40.68\%, H 6.59\%, N 1.60\% and S 0.197\% [31]. This composition i improved lipase secretion and supported biomass growth of M. spathulata R25L270.

The mixture of macaúba cake $(\mathrm{MC})$ with residual oil (RO) increased the lipase activity, probably due to the high amount of essential nutrients, mainly from $\mathrm{MC}$, and inducer concentration, mainly from RO. These increases can explain the significant interaction found between the two components of the mixture. Some microorganisms need inducers such as natural oils, fatty acids, fatty esters, sterols, bile salts and Tween to produce and secrete lipases [6]. The lipase activity depends on the inducer type and concentration of the fatty acid constituents of the substrate. Abdelmoez et al. [32] tested olive oil, fatty acid residues, soap stock and a mixture of these three components as inducers to obtain lipases by Candida rugosa ATCC 14830 . Lipase secretion was dependent on lipid type and concentration, and the maximum activities of the produced lipases utilising olive oil (0.5\%), fatty acid residues $(1.5 \%)$ and soapstock (1\%) were found to be 12,7 and 7.4 $\mathrm{U} \mathrm{mL}^{-1}$, respectively. Using a mixture of this substrate (the concentration is not mentioned), the lipase activity achieved was $10 \mathrm{U} \mathrm{mL}^{-1}$.

\section{Biochemical characterisation of lipases from M. spathulata R25L270}

Biochemical characterisation of new enzymes is critical to determining catalytic properties of the protein and their compatibility for use in bioprocesses. One important prerequisite for laboratory-scale tests and future industrial enzyme application is to determine the lipase storage stability. Therefore, the M. spathulata R25L270 
culture supernatant was stored in a refrigerator $\left(4^{\circ} \mathrm{C}\right)$, freezer $\left(-20^{\circ} \mathrm{C}\right)$, and ultra-freezer $\left(-80^{\circ} \mathrm{C}\right)$, and the enzyme activity was measured weekly for 1 month. As shown in Figure 2, the residual activity was at least $40 \%$ after 1 month of storage in a refrigerator $\left(4^{\circ} \mathrm{C}\right)$ and ultra-freezer $\left(-80^{\circ} \mathrm{C}\right)$. Crude lipases from Fusarium solani N4-2 retained almost 70 and $50 \%$ of the initial activity when stored for 1 month at $4^{\circ} \mathrm{C}$ and room temperature, respectively [33]. The crude lipase from Aspergillus japonicus retained approximately $80 \%$ of its initial activity after 4 weeks of storage at $-80^{\circ} \mathrm{C}$ [9]. As exemplified above, lipase storage stability depends on the enzyme source. The observed storage stability of lipase from M. spathulata R25L270 without the addition of stabilising agents indicates its potential use in bioprocesses.

In the present work, a central composite design was used to obtain a response surface model to explain the effect of reaction $\mathrm{pH}$ and temperature on lipase activity. Table 1 shows the combinations of the independent variables, reaction $\mathrm{pH}$ and temperature, and the respective observed and adjusted values and residual errors obtained for the response lipase activity (LA) $\left(\mathrm{U} \mathrm{mL}^{-1}\right)$.

The second-order polynomial model adjusted for lipase activity is given in Eq. 3.

$$
\mathrm{LA}=-5.489+0.104 \mathrm{~T}+1.886 \mathrm{P}-0.002 \mathrm{~T}^{2}-0.141 \mathrm{P}^{2}
$$

where LA corresponds to lipase activity $\left(\mathrm{U} \mathrm{mL}^{-1}\right)$, T corresponds to temperature, and $\mathrm{P}$ corresponds to $\mathrm{pH}$.

The ANOVA results indicated that the adjusted model is significant ( $\mathrm{p}$ value $=0.0001$ ), and $92.86 \%$ of the observed variation in the lipase activity can be explained by this model as indicated by the $\mathrm{R}^{2}$ value. The contour

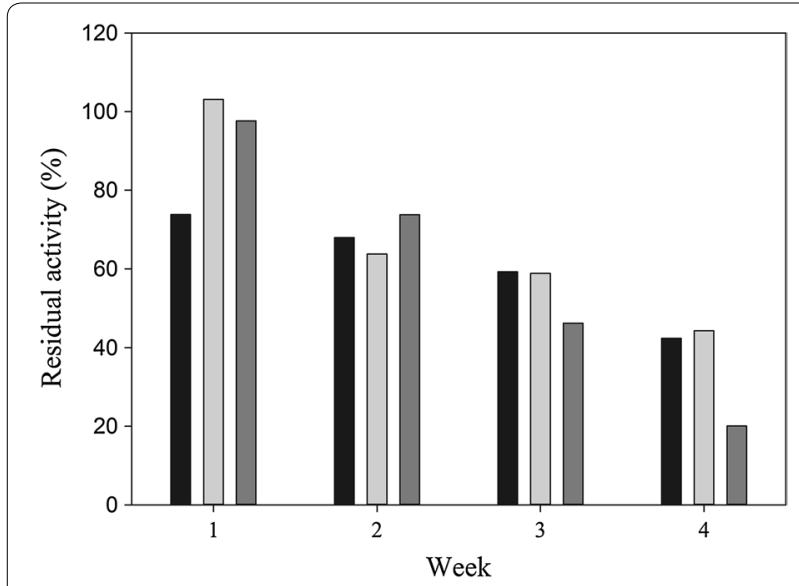

Figure 2 Storage stability of crude lipases from M. spathulata R25L270. Freezer $\left(-20^{\circ} \mathrm{C}\right)$ (dark gray), ultra-freezer $\left(-80^{\circ} \mathrm{C}\right)$ (light gray) and fridge $\left(4^{\circ} \mathrm{C}\right)$ (black). and response surface plots for the adjusted LA are shown in Figure 3. According to the adjusted model for LA, the maximal enzymatic activity $\left(2.47 \mathrm{U} \mathrm{mL}^{-1}\right)$ is achieved at $31.5^{\circ} \mathrm{C}$ and $\mathrm{pH} 6.7$. Additionally, at least $80 \%$ of the maximal activity value can be achieved by using different combinations of temperature $\left(25-48^{\circ} \mathrm{C}\right)$ and $\mathrm{pH}(6.5-8.4)$ ranges. This broad area of maximum performance allows the exploitation of many combinations of temperature and $\mathrm{pH}$, indicating the versatility of this enzyme and potential for application in different bioprocesses. These values are in accordance with those reported by Goldbeck and Filho [34], who studied the lipase from Metschnikowia pulcherrima for which the optimal range for temperature and $\mathrm{pH}$ was $37-47^{\circ} \mathrm{C}$ and $6.0-7.4$, respectively.

The thermostability of lipases from M. spathulata R25L270 was studied by incubation of crude supernatant in $50 \mathrm{mM}$ Tris- $\mathrm{HCl}$ buffer $(\mathrm{pH} 6.5-7.5-8.5)$ at 45 and $55^{\circ} \mathrm{C}$. As shown in Figure 4, of all the temperatures tested, the enzyme was most stable at $\mathrm{pH}$ 6.5. These results are in accordance with those obtained during the study of effect of $\mathrm{pH}$ and temperature on lipase activity. As shown in Figure 3, the enzyme activity decreases with increasing in $\mathrm{pH}$ and temperature, probably due the low enzyme stability under these conditions. The lipase from M. spathulata R25L270 retained $70 \%$ of the initial activity after incubation for $4 \mathrm{~h}$ at $45^{\circ} \mathrm{C}$ at $\mathrm{pH}$ 6.5. The thermostability of lipases from M. spathulata R25L270 was elevated compared to that obtained from other microbial sources such as Penicillum crustosum (25\% of initial enzymatic activity after incubation for $1 \mathrm{~h}$ at $45^{\circ} \mathrm{C}$ ) [28], Pseudomonas sp DMVR 46 (28\% of initial enzymatic activity after incubation for $4 \mathrm{~h}$ at $40^{\circ} \mathrm{C}$ ) [35] and Pichia lynferdii Y-7723 (35\% of initial enzymatic activity after incubation for $10 \mathrm{~min}$ at $50^{\circ} \mathrm{C}$ ) [36].

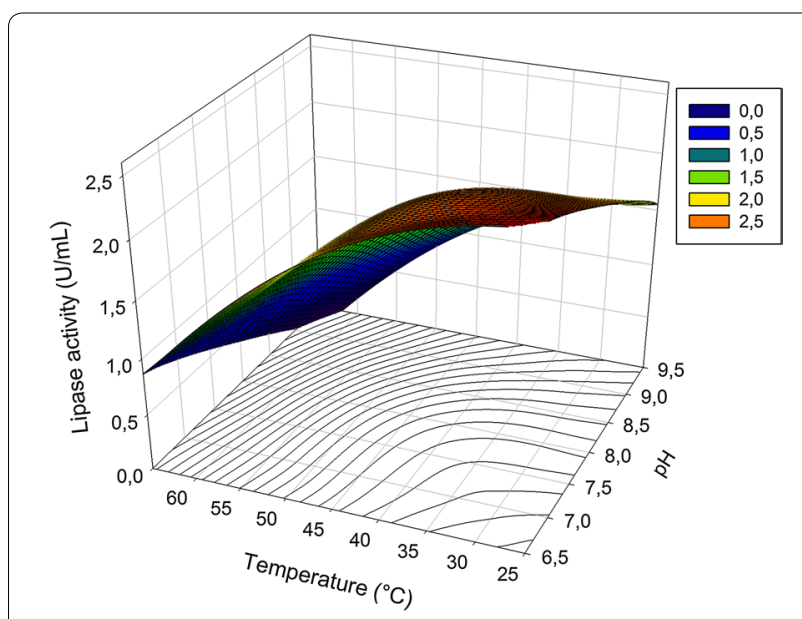

Figure 3 Response surface plot for adjusted lipase activity $\left(\mathrm{U} \mathrm{mL}^{-1}\right)$ versus reactional temperature $\left({ }^{\circ} \mathrm{C}\right)$ and $\mathrm{pH}$. 

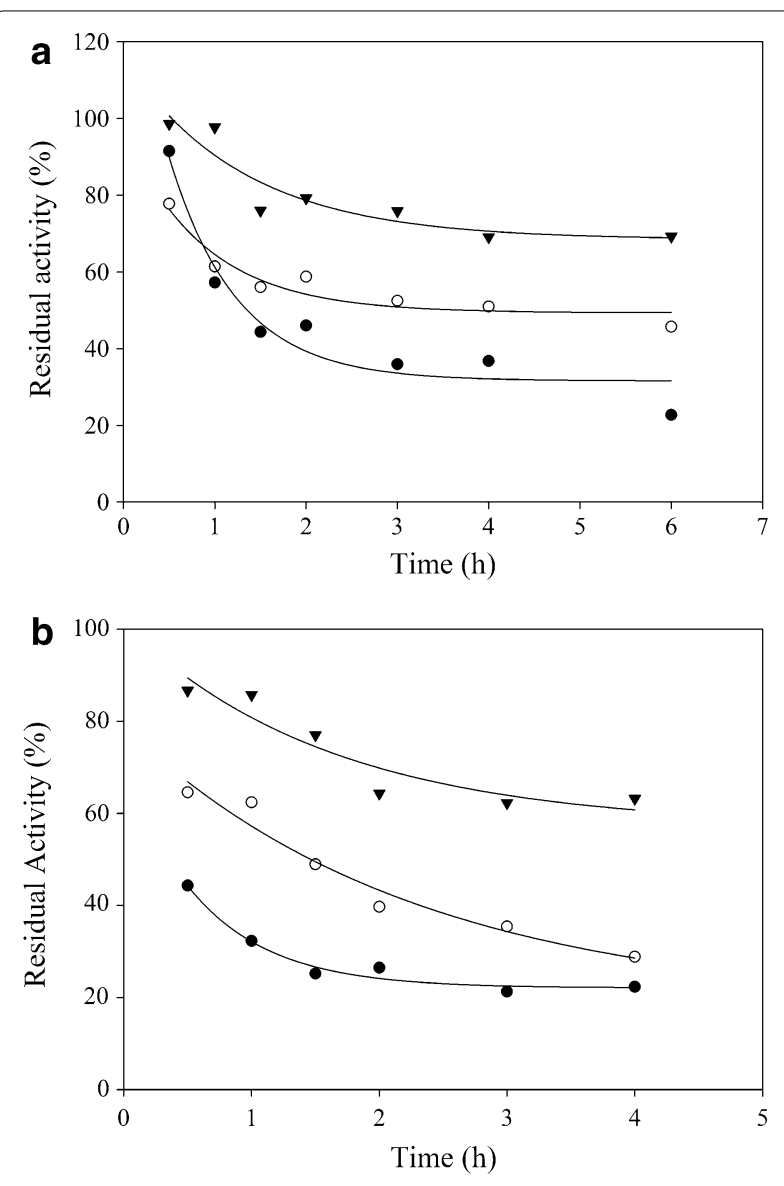

Figure 4 Thermostability of lipase from M. spathulata R25L270 was measured by incubating the lipase in $50 \mathrm{mM}$ TRIS-HCl buffer $\mathrm{pH} 8.5$ (black circle), pH 7.5 (white circle) and $\mathrm{pH} 6.5$ (triangle) at $45^{\circ} \mathrm{C}(\mathbf{a})$ and $50^{\circ} \mathrm{C}(\mathbf{b})$. Residual lipase activity (\%) was calculated relative to the initial activity.

The process of oil modification catalysed by lipases typically occurs at temperatures close to $40^{\circ} \mathrm{C}$, as observed for biodiesel production [5] and aroma synthesis [35]. The moderate temperature is necessary to homogenise the reaction medium due to the high oil viscosity and the existence of solid oil at room temperature. The thermostability observed for the novel lipases studied indicates that the culture supernatant containing the enzyme has the potential to be successfully applied in bioprocesses.

\section{Purification of lipases from M. spathulata R25L270 on phenyl-Sepharose}

The profile of total and glycosylated proteins in the culture supernatant of $M$. spathulata R25L270 grown in liquid medium supplemented with olive oil $(1 \% \mathrm{v} / \mathrm{v})$ is shown in Figure 5. The presence of lipase was confirmed by enzymatic activity on PAGE (zymogram) using tributyrin as a substrate. The yellow band resulting from the release of fatty acids (Figure 5) confirms the presence of a lipase in the supernatant. The extracellular lipase was purified by hydrophobic interaction. First, a crude extract was obtained by growing the yeast $M$. spathulata R25L270 in liquid media enriched with macaúba cake $\left(40 \mathrm{~g} \mathrm{~L}^{-1}\right)$. The interfacial adsorption of lipases on hydrophobic supports at low ionic strength is a simple method for one-step purification and immobilization of these enzymes [11]. The purification/immobilization of lipases from M. spathulata R25L270 on phenyl-Sepharose support at $5 \mathrm{mM}$ sodium phosphate buffer ( $\mathrm{pH} 7$ ) was carried out relatively rapidly, and almost $70 \%$ of the enzyme was adsorbed. The adsorbed enzymes were desorbed from the support by incubation in Triton X-100 solutions and the concentration of detergent required to fully desorb lipase activity was $0.09 \%$. The amount of detergent required to release lipases from hydrophobic support depends on the hydrophobic and internal morphology of the support and the properties of each enzyme [37]. SDS-PAGE analysis of the desorbed proteins showed the presence of two bands, one corresponding to a molecular weight of $>120 \mathrm{kDa}$ and other corresponding to a molecular weight of $>50 \mathrm{kDa}$, (Figure 6). These two proteins were subjected to analysis by mass spectrometry.

\section{Analysis by mass spectrometry}

The two bands previously described were excised from the gel, subjected to tryptic digestion and analysed by RP-LC-MS/MS in an Easy-nLC II system coupled to an ion trap LTQ-Orbitrap-Velos-Pro mass spectrometer. With 20 peptide sequences and $11.40 \%$ putative protein coverage, protein $1(>120 \mathrm{kDa})$ was identified as a protein from the transmembrane family MSFC (access: J6ET97) (Table 4). The second potential identification of protein 1 based on 9 peptide sequences and $17.86 \%$ putative protein coverage was a member of the lipase/esterase family (access: J6F4X8) (Table 4). Protein 2 ( $>50 \mathrm{kDa}$ ) was identified with 25 peptide sequences and $30.78 \%$ putative protein coverage as a member of the lipase-esterase family (access: J6F4X8); the other potential identity based on eight peptide sequences and $5.64 \%$ putative protein coverage was also a member of the protein transmembrane family MSFC (access: J6ET97) (Table 5). This finding suggests that both proteins are present in each band. The co-purification may have occurred due to the presence of hydrophobic regions on the surface of both proteins that bind to the support at low ionic strength.

\section{Application of lipases to catalyse vegetable and fish oil hydrolysis}

The inclusion of enzymatic processes to oil modification in the oleochemical industry is promising and leads 


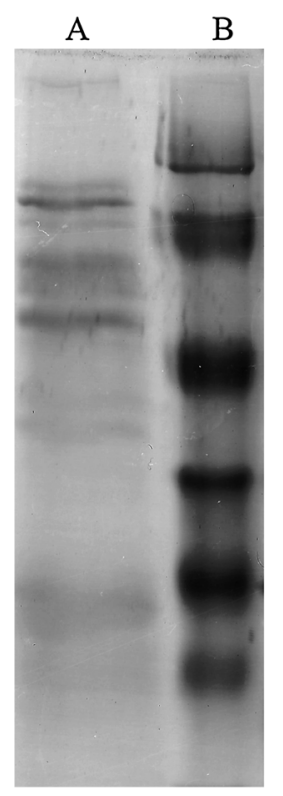

(I)

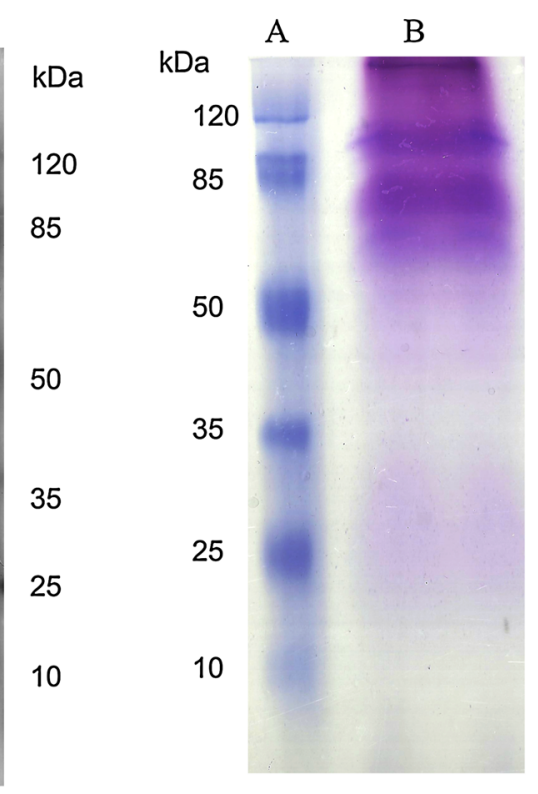

(II)

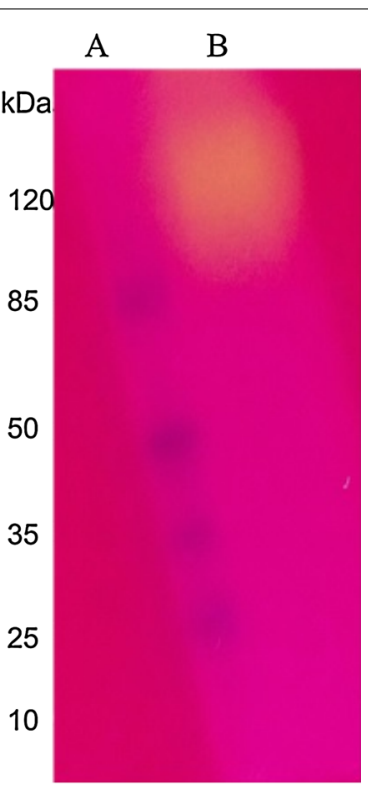

(III)

Figure 5 SDS-PAGE analysis: I Protein profile of crude supernatant obtained after growth of M. spathulata R25L270 for $120 \mathrm{~h}$ in liquid medium supplemented with olive oil. II Glycosylated protein profile of crude supernatant obtained after growth of M. spathulata R25L270 for $120 \mathrm{~h}$ in liquid medium supplemented with olive oil. III Zymographic analysis after SDS-NATIVE PAGE gel electrophoresis of crude supernatant obtained after growth of M. spathulata R25L270 for $120 \mathrm{~h}$ in liquid medium supplemented with olive oil.

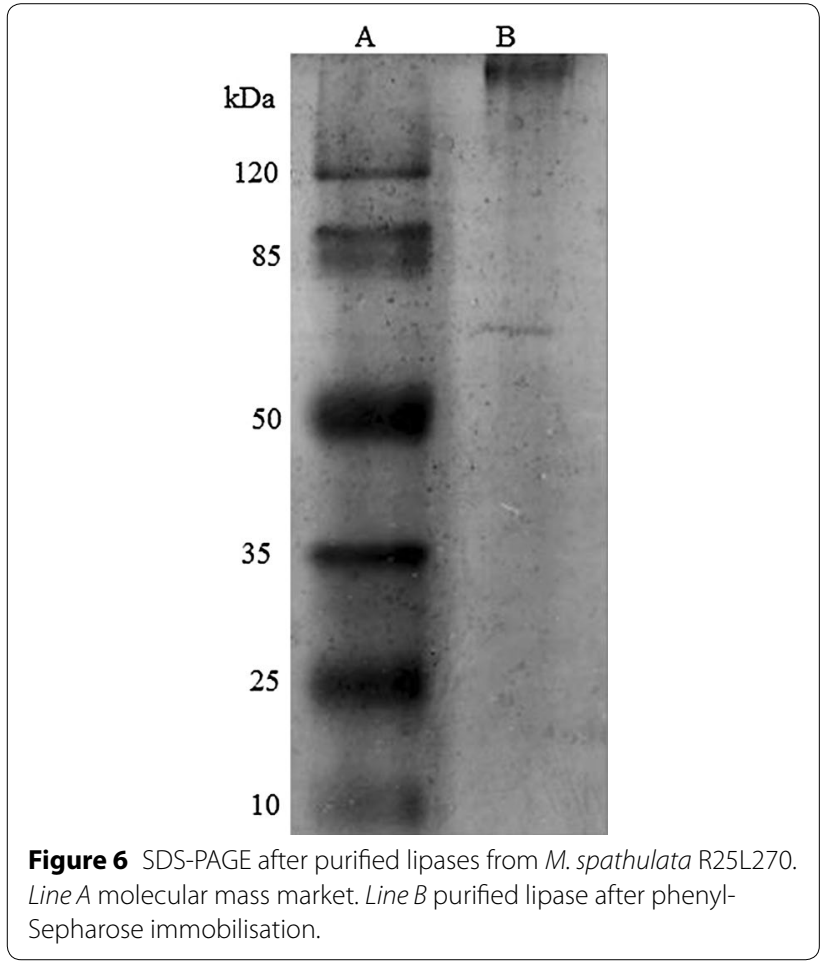

to improved environmental conditions, namely the lowest possible power consumption and waste generation. It also allows the production of unsaturated fatty acids without oxidation [7]. Fatty acids are currently produced by extreme conditions of temperature and pressure that promote the polymerisation of fats and formation of byproducts that need to be removed by purification and distillation steps [7]. In this context, the potential application of lipases from M. spathulata R25L270 for oil hydrolysis was determined using different vegetable oils emulsified with gum arabic solution. Table 6 shows that the enzyme was able to produce free fatty acids from all oils tested and preferentially catalysed sesame, olive and sunflower oils, showing enzymatic activity values of $46.86,43.26$ and $45.66 \mathrm{U} \mathrm{mg}^{-1}$, respectively.

The lipase from M. spathulata R25L270 exhibits interesting catalytic properties with regard to selectivity. Some lipases present specificity regarding the type of fatty acid and degree of saturation. Lipase selectivity depends on the enzyme form (e.g., free or immobilised), enzyme source (e.g., plant, animal, microbial), and reaction conditions (e.g., pH, solvents and temperature). These conditions alter the conformation and flexibility of the protein. The enzyme efficiently catalysed the selective hydrolysis of sardine oil. The release of omega-3 fatty acids [e.g., eicosapentaenoic acid (EPA) and docosahexaenoic acid (DHA)] from fish oil represents the first key step in the preparation of highly enriched triglyceride products, which have been described as excellent functional ingredients [18]. As shown in Table 7, the release rate of EPA 
Table 4 Peptides sequence of protein band 1 (>120 kDa)

\begin{tabular}{|c|c|c|c|c|c|c|c|}
\hline $\mathrm{A} 2$ & Sequence & $\begin{array}{l}\text { Protein group } \\
\text { accessions }\end{array}$ & Modifications & XCorr & Charge & $\mathrm{MH}+[\mathrm{Da}]$ & $m / z[D a]$ \\
\hline High & cQAADIVSSLNLQR & J6ET97 & C1 (carbamidomethyl) & 5.48 & 2 & $1,574.78203$ & 787.89465 \\
\hline High & cPASDLTAALALSEKK & J6ET97 & C1 (carbamidomethyl) & 5.43 & 3 & $1,674.86588$ & 558.96014 \\
\hline High & CPASDLTAALALSEK & J6ET97 & C1 (carbamidomethyl) & 5.14 & 2 & $1,546.77275$ & 773.89001 \\
\hline High & FTNMASDCLQAK & J6ET97 & C8 (carbamidomethyl) & 4.76 & 2 & $1,385.61138$ & 693.30933 \\
\hline High & SQDDTACVcTDAYR & J6ET97 & $\begin{array}{l}\text { C7 (carbamidomethyl); } \\
\text { C9 (carbamidomethyl) }\end{array}$ & 4.74 & 2 & $1,661.63713$ & 831.32220 \\
\hline High & CPSDITAALALQSK & J6ET97 & C1 (carbamidomethyl) & 4.65 & 2 & $1,474.75029$ & 737.87878 \\
\hline High & CQAADIVSSLNLQR & J6ET97 & & 4.14 & 2 & $1,517.76433$ & 759.38580 \\
\hline High & FTNmASDcLQAK & J6ET97 & M4 (oxidation); C8 (carbamidomethyl) & 4.01 & 2 & $1,401.60527$ & 701.30627 \\
\hline High & AGcSGPTDTGCLCTEK & J6ET97 & $\begin{array}{l}\text { C3 (carbamidomethyl); C11 (carbamido- } \\
\text { methyl); C13 (carbamidomethyl) }\end{array}$ & 4.00 & 2 & $1,713.67314$ & 857.34021 \\
\hline High & LNFSTSTmGcLmK & J6ET97 & $\begin{array}{l}\text { M8 (oxidation); C10 (carbamidomethyl); } \\
\text { M12 (oxidation) }\end{array}$ & 3.90 & 2 & $1,521.66594$ & 761.33661 \\
\hline High & LSPCALSCVLDTLGK & J6ET97 & $\begin{array}{l}\text { C4 (carbamidomethyl); } \\
\text { C8 (carbamidomethyl) }\end{array}$ & 3.71 & 2 & $1,633.82121$ & 817.41425 \\
\hline High & DLmDALALSSK & J6ET97 & M3 (oxidation) & 3.69 & 2 & $1,179.58745$ & 590.29736 \\
\hline High & DLMDALALSSK & J6ET97 & & 3.69 & 2 & $1,163.59197$ & 582.29962 \\
\hline High & NNAAGCLTSNSK & J6ET97 & C6 (carbamidomethyl) & 3.65 & 2 & $1,236.55840$ & 618.78284 \\
\hline High & CLIDAAAQLGCK & J6ET97 & $\begin{array}{l}\text { C1 (carbamidomethyl); } \\
\text { C11 (carbamidomethyl) }\end{array}$ & 3.59 & 2 & $1,319.64287$ & 660.32507 \\
\hline High & LNFSTSTmGcLMK & J6ET97 & M8 (oxidation); C10 (carbamidomethyl) & 3.52 & 2 & $1,505.67363$ & 753.34045 \\
\hline High & GSSDVCEATGIWR & J6ET97 & & 3.48 & 2 & $1,380.61418$ & 690.81073 \\
\hline High & cLVDAAATHGCK & J6ET97 & $\begin{array}{l}\text { C1 (carbamidomethyl); } \\
\text { C11 (carbamidomethyl) }\end{array}$ & 3.42 & 2 & $1,302.58611$ & 651.79669 \\
\hline High & GSSDVCEATGIWR & J6ET97 & C6 (carbamidomethyl) & 3.24 & 2 & $1,437.63799$ & 719.32263 \\
\hline High & LSPCALSCVLDTLGK & J6ET97 & C8 (carbamidomethyl) & 2.96 & 2 & $1,576.79521$ & 788.90125 \\
\hline High & LAALLGDAVFTLTR & $\mathrm{J} 6 \mathrm{~F} 4 \mathrm{X} 8$ & & 4.88 & 2 & $1,460.83855$ & 730.92291 \\
\hline High & GAImNSGSmVPVDPVDGSR & $\mathrm{J} 6 \mathrm{~F} 4 \mathrm{X} 8$ & M4 (oxidation); M9 (oxidation) & 4.85 & 2 & $1,920.86870$ & 960.93799 \\
\hline High & SYGTGIEALNYGSPHR & $\mathrm{J} 6 \mathrm{~F} 4 \mathrm{X} 8$ & & 4.37 & 2 & $1,721.81670$ & 861.41199 \\
\hline High & GAIMNSGSmVPVDPVDGSR & $\mathrm{J} 6 \mathrm{~F} 4 \mathrm{X} 8$ & M9 (oxidation) & 4.21 & 2 & $1,904.87224$ & 952.93976 \\
\hline High & SGLDVGKPFVFVAVNYR & $\mathrm{J} 6 \mathrm{~F} 4 \mathrm{X} 8$ & & 4.09 & 3 & $1,867.99619$ & 623.33691 \\
\hline High & AEGIGNLGLLDQR & $\mathrm{J} 6 \mathrm{~F} 4 \mathrm{X} 8$ & & 3.54 & 2 & $1,355.71794$ & 678.36261 \\
\hline Medium & TGIFNEIYPGFK & $\mathrm{J} 6 \mathrm{~F} 4 \mathrm{X} 8$ & & 3.44 & 2 & $1,385.69707$ & 693.35217 \\
\hline High & ISEDcLTVNVIRPK & $\mathrm{J} 6 \mathrm{~F} 4 \mathrm{X} 8$ & C5 (carbamidomethyl) & 3.11 & 2 & $1,643.87175$ & 822.43951 \\
\hline High & GAIMNSGSMVPVDPVDGSR & $\mathrm{J} 6 \mathrm{~F} 4 \mathrm{X} 8$ & & 2.69 & 2 & $1,888.88420$ & 944.94574 \\
\hline
\end{tabular}

J6ET97 [description: uncharacterized protein OS = Trichosporon asahii var. asahii (strain ATCC 90039/CBS 2479/JCM 2466/KCTC 7840/NCYC 2677/UAMH 7654) $\mathrm{GN}=\mathrm{A1Q1} 03255 \mathrm{PE}=4 \mathrm{SV}=1-(\mathrm{J6ET97}$ TRIAS)] and J6F4X8 [uncharacterized protein OS = Trichosporon asahii var. asahii (strain ATCC 90039/CBS 2479/JCM 2466/ KCTC 7840/NCYC 2677/UAMH 7654) GN = A1Q1_00392 PE = 4 SV = 1 - (J6F4X8_TRIAS)].

was approximately fivefold higher than the release of DHA, especially during the first hour of the reaction. The EPA/DHA selectivity of this new extracellular lipase could make it attractive for industrial application, e.g., allowing the production of 5:1 EPA:DHA mixtures from sardine oil hydrolysis. Based on the results obtained in the present study, we speculate that the lipase from $M$. spathulata R25L270, which showed potential for degrading different oils and substrate selectivity, has potential for application in the oleochemical industry and also in oil-laden effluent treatment.

\section{Conclusions}

A mixture of macaúba cake and residual oil instead of olive oil was successfully used for induction of lipase secretion by M. spathulata R25L270. The lipase functionality in a wide temperature and $\mathrm{pH}$ range revealed its potential for utilisation in bioprocesses. The enzyme efficiently 
Table 5 Peptides sequence of protein 2 (>50 kDa)

\begin{tabular}{|c|c|c|c|c|c|c|c|}
\hline A2 & Sequence & $\begin{array}{l}\text { Protein group } \\
\text { accessions }\end{array}$ & Modifications & XCorr & Charge & $\mathrm{MH}+[\mathrm{Da}]$ & $m / z[D a]$ \\
\hline High & LAALLGDAVFTLTR & $\mathrm{J} 6 \mathrm{~F} 4 \mathrm{X} 8$ & & 5.12 & 2 & $1,460.84380$ & 730.92554 \\
\hline High & PDGVFMTDSPDNLVSNKK & $\mathrm{J} 6 \mathrm{~F} 4 \mathrm{X} 8$ & & 4.94 & 3 & $1,963.93851$ & 655.31769 \\
\hline High & SGLDVGKPFVFVAVNYR & $\mathrm{J} 6 \mathrm{~F} 4 \mathrm{X} 8$ & & 4.85 & 2 & $1,867.99834$ & 934.50281 \\
\hline High & PDGVFmTDSPDNLVSNK & $\mathrm{J} 6 \mathrm{~F} 4 \mathrm{X} 8$ & M6 (oxidation) & 4.81 & 2 & $1,851.83696$ & 926.42212 \\
\hline High & GAImNSGSmVPVDPVDGSR & $\mathrm{J} 6 \mathrm{~F} 4 \mathrm{X} 8$ & M4 (oxidation); M9 (oxidation) & 4.66 & 2 & $1,920.87639$ & 960.94183 \\
\hline High & PDGVFMTDSPDNLVSNK & $\mathrm{J} 6 \mathrm{~F} 4 \mathrm{X} 8$ & & 4.58 & 2 & $1,835.84026$ & 918.42377 \\
\hline High & PDGVFmTDSPDNLVSNKK & $\mathrm{J} 6 \mathrm{~F} 4 \mathrm{X} 8$ & M6 (oxidation) & 4.53 & 3 & $1,979.92801$ & 660.64752 \\
\hline High & SYGTGIEALNYGSPHR & $\mathrm{J} 6 \mathrm{~F} 4 \mathrm{X} 8$ & & 4.42 & 2 & $1,721.81645$ & 861.41187 \\
\hline High & GAImNSGSMVPVDPVDGSR & $\mathrm{J} 6 \mathrm{~F} 4 \mathrm{X} 8$ & M4 (oxidation) & 4.30 & 2 & $1,904.87676$ & 952.94202 \\
\hline High & ISEDCLTVNVIRPK & $\mathrm{J} 6 \mathrm{~F} 4 \mathrm{X} 8$ & & 4.14 & 2 & $1,586.83379$ & 793.92053 \\
\hline High & AEGIGNLGLLDQR & $\mathrm{J} 6 \mathrm{~F} 4 \mathrm{X} 8$ & & 4.14 & 2 & $1,355.72612$ & 678.36670 \\
\hline High & TGIFNEIYPGFK & $\mathrm{J} 6 \mathrm{~F} 4 \mathrm{X} 8$ & & 3.80 & 2 & $1,385.70098$ & 693.35413 \\
\hline High & ISEDCLTVNVIRPK & $\mathrm{J} 6 \mathrm{~F} 4 \mathrm{X} 8$ & C5 (carbamidomethyl) & 3.73 & 2 & $1,643.87407$ & 822.44067 \\
\hline High & GAIMNSGSMVPVDPVDGSR & $\mathrm{J} 6 \mathrm{~F} 4 \mathrm{X} 8$ & & 3.67 & 2 & $1,888.88225$ & 944.94476 \\
\hline Medium & AGcDTAPDSLQCLR & $\mathrm{J} 6 \mathrm{~F} 4 \mathrm{X} 8$ & $\begin{array}{l}\text { C3 (carbamidomethyl); } \\
\text { C12 (carbamidomethyl) }\end{array}$ & 3.50 & 2 & $1,563.68144$ & 782.34436 \\
\hline Medium & ISEDCLTVNVIR & $\mathrm{J} 6 \mathrm{~F} 4 \mathrm{X} 8$ & C5 (carbamidomethyl) & 3.49 & 2 & $1,418.72783$ & 709.86755 \\
\hline High & KAGCDTAPDSLQcLR & $\mathrm{J} 6 \mathrm{~F} 4 \mathrm{X} 8$ & $\begin{array}{l}\text { C4 (carbamidomethyl); } \\
\text { C13 (carbamidomethyl) }\end{array}$ & 3.41 & 3 & $1,691.77201$ & 564.59552 \\
\hline High & KDPLVNWDATK & $\mathrm{J} 6 \mathrm{~F} 4 \mathrm{X} 8$ & & 3.33 & 2 & $1,286.66814$ & 643.83771 \\
\hline High & QLINFYAmYFK & $\mathrm{J} 6 \mathrm{~F} 4 \mathrm{X} 8$ & M8 (oxidation) & 3.32 & 2 & $1,453.71562$ & 727.36145 \\
\hline High & ISEDCLTVNVIR & $\mathrm{J} 6 \mathrm{~F} 4 \mathrm{X} 8$ & & 3.29 & 2 & $1,361.70427$ & 681.35577 \\
\hline High & PFVFVAVNYR & J6F4X8; N4V6R7 & & 3.28 & 2 & $1,211.65520$ & 606.33124 \\
\hline Medium & QLINFYAMYFK & $\mathrm{J} 6 \mathrm{~F} 4 \mathrm{X} 8$ & & 3.17 & 2 & $1,437.72014$ & 719.36371 \\
\hline Medium & TAYGALGLRL & $\mathrm{J} 6 \mathrm{~F} 4 \mathrm{X} 8$ & & 3.11 & 2 & $1,034.59783$ & 517.80255 \\
\hline Medium & VAGWGFMPGK & $\mathrm{J} 6 \mathrm{~F} 4 \mathrm{X} 8$ & & 3.07 & 2 & $1,049.52117$ & 525.26422 \\
\hline High & TGIFNEIYPGFKR & $\mathrm{J} 6 \mathrm{~F} 4 \mathrm{X} 8$ & & 2.89 & 3 & $1,541.80661$ & 514.60706 \\
\hline High & CPASDLTAALALSEK & J6ET97 & C1 (carbamidomethyl) & 4.46 & 2 & $1,546.77397$ & 773.89063 \\
\hline High & cQAADIVSSLNLQR & J6ET97 & C1 (carbamidomethyl) & 4.23 & 2 & $1,574.78728$ & 787.89728 \\
\hline High & FTNMASDCLQAK & J6ET97 & C8 (carbamidomethyl) & 4.18 & 2 & $1,385.61431$ & 693.31079 \\
\hline High & DLmDALALSSK & J6ET97 & M3 (oxidation) & 3.80 & 2 & $1,179.59075$ & 590.29901 \\
\hline High & NNAAGCLTSNSK & J6ET97 & C6 (carbamidomethyl) & 3.72 & 2 & $1,236.55889$ & 618.78308 \\
\hline High & CPSDITAALALQSK & J6ET97 & C1 (carbamidomethyl) & 3.70 & 2 & $1,474.75408$ & 737.88068 \\
\hline High & DLMDALALSSK & J6ET97 & & 3.56 & 2 & $1,163.59526$ & 582.30127 \\
\hline Medium & CPASDLTAALALSEKK & J6ET97 & C1 (carbamidomethyl) & 3.06 & 3 & $1,674.86753$ & 558.96069 \\
\hline
\end{tabular}

J6ET97 [description: uncharacterized protein OS = Trichosporon asahii var. asahii (strain ATCC 90039/CBS 2479/JCM 2466/KCTC 7840/NCYC 2677/UAMH 7654) GN = A1Q1_03255 PE = 4 SV = 1 - (J6ET97_TRIAS)] and J6F4X8 [uncharacterized protein OS = Trichosporon asahii var. asahii (strain ATCC 90039/CBS 2479/JCM 2466/ KCTC 7840/NCYC 2677/UAMH 7654) GN = A1Q1_00392 PE = 4 SV = $1-($ J6F4X8_TRIAS)].

Table 6 Hydrolyzes of commercial oils by lipase from M. spathulata R25L270

\begin{tabular}{lcl}
\hline Vegetal oil & Fatty acid ( $\mathbf{m m o l e s})$ & Hydrolysis activity $\left(\mathbf{U ~ m g}^{\mathbf{- 1}}\right)$ \\
\hline Corn & $46.50 \pm 9.30$ & $36.05 \pm 7.21$ \\
Soya & $52.70 \pm 5.37$ & $33.64 \pm 4.16$ \\
Sesame & $116.25 \pm 6.57$ & $46.86 \pm 5.10$ \\
Almond & $55.80 \pm 9.30$ & $36.05 \pm 7.21$ \\
Olive & $58.90 \pm 10.74$ & $43.26 \pm 0.0$ \\
Canola & $46.50 \pm 9.30$ & $36.05 \pm 7.21$ \\
Sunflower & $58.90 \pm 5.37$ & $45.66 \pm 4.16$
\end{tabular}

Table 7 Hydrolysis of sardine oil catalyzed by $M$. spathuIata R25L270 lipase and ratio between the releases of EPA versus the release of DHA during the time

\begin{tabular}{llll}
\hline Time $(\mathbf{h})$ & EPA $(\boldsymbol{\mu M})$ & DHA $(\boldsymbol{\mu M})$ & Ratio (EPA/DHA) \\
\hline 24 & 17.68 & 3.56 & 4.97 \\
48 & 20.93 & 5.24 & 3.99 \\
72 & 37.01 & 11.94 & 3.10 \\
96 & 45.20 & 14.31 & 3.16 \\
120 & 54.23 & 19.34 & 2.80 \\
\hline
\end{tabular}

EPA eicosapentaenoic acid, DHA docosahexaenoic acid 
hydrolysed different oils and showed selectivity for generating EPA from fish oil. This is the first study demonstrating the use of macaúba cake as a substrate for lipase production and the application of lipases from M. spathulata in oil hydrolysis. Lipase immobilisation is a strategy to explore the lipolytic potential of this new lipase source.

\begin{abstract}
Abbreviations
MC: macaúba cake; RO: residual oil; EPA: eicosapentaenoic acid; GYMP broth: glucose, yeast extract, malt extract, $\mathrm{NaH}_{2} \mathrm{PO}_{4}$ and glycerol; $\boldsymbol{p}$-NPP: $\boldsymbol{p}$-nitrophenyl palmitate; $p N P$ : $p$-nitrophenol; SDS-PAGE: sodium dodecyl sulfate polyacrylamide gel electrophoresis; MS: mass spectrometry; ACN: acetonitriler; RP-LCMS/MS: reverse phase liquid chromatography mass spectrometry in tandem; FDR: false discovery rate; LA: supernatant lipase activity; LP: supernatant total protein
\end{abstract}

\section{Authors' contributions}

LTAS carried out in the hydrolysis of vegetal and fish oil, SDS-PAGE, protein identification by mass spectrometry, analysis of lipase activity assay, biochemical characterisation of M. spathulata R25L270 lipase, experimental procedure for lipase production using biodiesel wastes, and drafted the manuscript JSO carried out the chromatography experiments. MQRBR performed the statistical analysis and participated in the biochemical characterisation of $M$. spathulata R25L270 lipase. VLS participated in the design of the study and helped to lipase production assays. BCP participated in the design of the study, performed the statistical analysis and helped to revise the manuscript. BCP and RRR conceived of the study, and participated in its design and coordination and helped to draft the manuscript. All authors read and approved the final manuscript.

\section{Author details}

1 Departamento de Bioquímica e Imunologia, Universidade Federal de Minas Gerais, Av Antônio Carlos 6627, Pampulha, Caixa Postal 486, Belo Horizonte, MG 31270-901, Brazil. ${ }^{2}$ Departamento de Microbiologia, Universidade Federal de Minas Gerais, Av Antônio Carlos 6627, Caixa Postal 486, Belo Horizonte, MG 31270-901, Brazil. ${ }^{3}$ Departamento de Biotecnología y Microbiología de Alimentos, Instituto de Investigación en Ciencias de la Alimentación CIAL (CSIC-UAM), Campus de la Universidad Autónoma de Madrid, Nicolás Cabrera 9, 28049 Madrid, Spain. ${ }^{4}$ Instituto Nanocell and Departamento de Bioquímica e Imunologia, Instituto de Ciências Biológicas, Universidade Federal de Minas Gerais, Av Antônio Carlos 6627, Pampulha, Caixa Postal 486, Belo Horizonte, MG 31270-901, Brazil.

\section{Acknowledgements}

The authors would like to thank Dr. José Antonio Saraiva Grossi and MSc. Anderson Barbosa Evaristo for providing biodiesel processing wastes and Dr. Carlos Augusto Rosa for providing the strain M. sphatulata R25L270. This research was supported by Brazilian agencies: CNPq (Conselho Nacional de Desenvolvimento Científico e Tecnológico), INCT (Instituto Nacional de Ciência e Tecnologia) de Nanomateriais de Carbono, FAPEMIG (Fundação de Amparo à Pesquisa do Estado de Minas Gerais), Rede Mineira de Toxinas com Ação Terapêutica and CAPES (Coordenação de Aperfeiçoamento de Pessoal de Nível Superior).

\section{Compliance with ethical guidelines}

\section{Competing interests}

The authors declare that they have no competing interests.

Received: 27 March 2015 Accepted: 18 May 2015

Published online: 16 June 2015

\section{References}

1. Aransiola EF, Ojumu TV, Oyekola OO, Madzimbamuto TF, Ikhu-Omoregbe DIO (2014) A review of current technology for biodiesel production: state of the art. Biomass Bioenerg 61:276-297
2. Yang F, Hanna MA, Sun R (2012) Value-added uses for crude glycerol-a byproduct of biodiesel production. Biotechnol Biofuels 5:13

3. Salihu A, Alam MZ, AbdulKarim MI, Salleh HM (2012) Lipase production: an insight in the utilization of renewable agricultural residues. Resour Conserv Recycl 58:36-44

4. Moura EF, Ventrella MC, Motoike SY (2010) Anatomy, histochemistry and ultrastructure of seed and somatic embryo of Acrocomia aculeata (Arecaceae). Scientia Agricola 64:399-407

5. Aguieiras E, Cavalcanti-Oliveira E (2014) Biodiesel production from Acrocomia aculeata acid oil by (enzyme/enzyme) hydroesterification process: use of vegetable lipase and fermented solid as low-cost biocatalysts. Fuel 135:315-321

6. Singh AK, Mukhopadhyay M (2012) Overview of fungal lipase: a review. Appl Biochem Biotechnol 166:486-520

7. AbdelmoezW, Mustafa A (2014) Oleochemical industry future through biotechnology. J Oleo Sci 63:545-554

8. Vakhlu J, Kour A (2006) Yeast lipases: enzyme purification, biochemical properties and gene cloning. Electron J Biotechnol 9:69-85

9. Souza L, Oliveira JS, Santos VL, Regis WCB, Santoro MM, Resende RR (2014) Lipolytic potential of Aspergillus japonicus LAB01: production, partial purification, and characterisation of an extracellular lipase. Biomed Res Int 2014:1-11

10. Winkler UK, Stuckmann M (1979) Glycogen, hyaluronate, and some other polysaccharides greatly enhance the formation of exolipase by Serratia marcescens. J Bacteriol 138:663-670

11. Bastida A, Sabuquillo P, Armisen P, Huguet J, Guisa M (1998) A single step purification, immobilization, and hyperactivation of lipases via interfacial adsorption on strongly hydrophobic supports. Biotechol Eng 58:486-493

12. Laemmli UK (1970) Cleavage of structural proteins during the assembly of the head of bacteriophage T4. Nature 227:680-685

13. Bradford M (1976) Rapid and sensitive method for quantification of microgram quantities of protein utilizing principle of protein-dye-binding. Anal Biochem 72:248-254

14. Zacharius RM, Zell TE, Morrison JH, Woodlock JJ (1969) Glycoprotein staining following electrophoresis on acrylamide gels. Anal Biochem 30:148-152

15. Singh R, Gupta N, Goswami VK, Gupta R (2006) A simple activity staining protocol for lipases and esterases. Appl Microbiol Biotechnol 70:679-682

16. Shevchenko A, Wilm M, Vorm O, Mann M (1996) Mass spectrometric sequencing of proteins from silver-stained polyacrylamide gels. Anal Chem 68:850-858

17. Soares CMF, De Castro HF, De Moraes FF, Zanin GM (1999) Characterization and utilization of Candida rugosa lipase immobilized on controlled pore silica. Appl Bichem Biotechnol 77-79:745-757

18. Fernández-Lorente G, Pizarro C, López-Vela D, Betancor L, Carrascosa AV, Pessela B, Guisan JM (2010) Hydrolysis of fish oil by lipases immobilized inside porous supports. J Am Oil Chem Soc 88:819-826

19. Ohnishi K, Yoshida Y, Sekiguchi J (1994) Lipase production of Aspergillus oryzae. J Ferment Bioeng 77:490-495

20. Fickers P, Nicaud JM, Gaillardin C, Destain J, Thonart P (2004) Carbon and nitrogen sources modulate lipase production in the yeast Yarrowia lipolytica. J Appl Microbiol 96:742-749

21. De Almeida AF, Taulk-Tornisielo SM, Carmona EC (2012) Influence of carbon and nitrogen sources on lipase production by a newly isolated Candida viswanathii strain. Ann Microbiol 63:1225-1234

22. Van Gerpen J (2005) Biodiesel processing and production. Fuel Process Technol 86:1097-1107

23. De Souza Monteiro A, Domingues V, Souza MV, Lula I, Gonçalves D, de Siqueira EP, dos Santos V (2012) Bioconversion of biodiesel refinery waste in the bioemulsifier by Trichosporon mycotoxinivorans CLA2. Biotechnol Biofuels 5:29

24. Kumar S, Katiyar N, Ingle P, Negi S (2011) Use of evolutionary operation (EVOP) factorial design technique to develop a bioprocess using grease waste as a substrate for lipase production. Bioresour Technol 102:4909-4912

25. Pereira-Meirelles FV, Rocha-Leão MH, Sant Anna GL Jr (2000) Lipase location in Yarrowia lipolytica cells. Biotechnol Lett 22(1):71-75

26. Gutarra MLE, Godoy MG, Castilho LR, Freire DMG (2007) Inoculum strategies for Penicillium simplicissimum lipase production by solid-state fermentation using a residue from the babassu oil industry. J Chem Technol Biotechnol 18:313-318 
27. Veerabhadrappa MB, Shivakumar SB, Devappa S (2014) Solid-state fermentation of Jatropha seed cake for optimization of lipase, protease and detoxification of anti-nutrients in Jatropha seed cake using Aspergillus versicolor CJS-98. J Biosci Bioeng 117:208-214

28. Rigo E, Ninow JL, Tsai SM, Durrer A, Foltran LL, Remonatto D, Sychoski M, Vardanega R, de Oliveira D, Treichel H, Di Luccio M (2010) Preliminary characterization of novel extra-cellular lipase from Penicillium crustosum under solid-state fermentation and its potential application for triglycerides hydrolysis. Food Bioprocess Technol 5:1592-1600

29. Sethi BK, Rout JR, Das R, Nanda PK, Sahoo SL (2012) Lipase production by Aspergillus terreus using mustard seed oil cake as a carbon source. Ann Microbiol 63:241-252

30. Rajendran A, Thangavelu V (2012) Utilizing agricultural wastes as substrates for lipase production by Candida rugosa NCIM 3462 in solid-state fermentation: response surface optimization of fermentation parameters. Waste Biomass Valoriz 4:347-357

31. Vieira SS, Magriotis ZM, Cardoso MG, Saczk AA (2012) Macauba palm (Acrocomia aculeata) cake from biodiesel processing: an efficient and low cost substrate for the adsorption of dyes. Chem Eng J 183:152-161
32. Abdelmoez W, Mostafa NA, Mustafa A (2013) Utilization of oleochemical industry residues as substrates for lipase production for enzymatic sunflower oil hydrolysis. J Clean Prod 59:290-297

33. Liu R, Jiang X, Mou H, Guan H, Hwang H, Li X (2009) A novel low-temperature resistant alkaline lipase from a soda lake fungus strain Fusarium solani N4-2 for detergent formulation. Biochem Eng J 46:265-270

34. Goldbeck R, Filho FM (2013) Screening, characterization, and biocatalytic capacity of lipases producing wild yeasts from Brazil biomes. Food Sci Biotechnol 22:79-87

35. Patel V, Nambiar S, Madamwar D (2014) An extracellular solvent stable alkaline lipase from Pseudomonas sp. DMVR46: partial purification, characterization and application in non-aqueous environment. Process Biochem 49:1673-1681

36. Bae J-H, Kwon M-H, Kim I-H, Hou CT, Kim H-R (2014) Purification and characterization of a cold-active lipase from Pichia lynferdii Y-7723: $\mathrm{pH}$ dependant activity deviation. Biotechnol Bioprocess Eng 19:851-857

37. Volpato G, Filice M, Ayub MAZ, Guisan JM, Palomo JM (2010) Single-step purification of different lipases from Staphylococcus warneri. J Chromatogr A 1217:473-478

\section{Submit your next manuscript to BioMed Central and take full advantage of:}

- Convenient online submission

- Thorough peer review

- No space constraints or color figure charges

- Immediate publication on acceptance

- Inclusion in PubMed, CAS, Scopus and Google Scholar

- Research which is freely available for redistribution

Submit your manuscript at

www.biomedcentral.com/submit

() Biomed Central 